\title{
Build With Heart for People's welfare ${ }^{1}$
}

\author{
Afrizal Tjoetra \\ Lecturer Sociology Program-FISIP \\ Teuku Umar University (UTU), Meulaboh, West Aceh. \\ S3 students in the Faculty of Social Community in Universiti Sains \\ Malaysia (USM), \\ Penang - Malaysia. Email: atjoetra@gmail.com
}

\begin{abstract}
Typically, the development process set forth in the Medium Term Development Plan (Plan) district / city and province. Derivative development agenda in the form of a series of programs is reflected in the Budget (APBK) district / city and province. Considering the people as direct beneficiaries of development, so it will need public participation, both in the planning, implementation and monitoring and evaluation. If space is available and effective consultation in the district / city? This paper is intended to arouse stakeholders about the importance of the availability of space and the public consultation on the regional development strategy of the future. According to the theory, the development process can be criticized conducted through two main concepts, namely the modernization theory and dependency theory. The important lesson to be learned from the experience of 10 figures is the first elected regional leaders, for example, and honesty. Secondly, it turns out the area is able to take care of themselves. Third, there must be a rejection of the classical phenomenon of bureaucracy that is corruption, inefficiency, working without vision. Fourth, the intense communication is the key to success, and the fifth is impatient to hear the complaints of the people and work to achieve it.
\end{abstract}

Keywords: Development, Public Participation and Public Consultation Room.

Tulisan ini --dengan sejumlah perbaikan--telah disampaikan pada kegiatan Roadshow Konsorsium Aceh Baru untuk Sosialisasi Skenario Aceh Baru, pada 29 Mai 2009 di Tapaktuan - Aceh Selatan. 
Negara harus bebaskan biaya pendidikan Negara harus bebaskan biaya kesehatan Negara harus ciptakan pekerjaan Negara harus adil, tidak memihak

Itulah tugas negara Itulah gunanya negara Itulah artinya negara Tempat kita bersandar dan berharap

Kenapa tidak orang kita kaya raya Baik alamnya maupun manusianya Dan kini yang kita pelajari sejak bayi Hanya saja kita tak pandai mengolahnya

\section{Pengantar}

Cuplikan di atas adalah lirik lagu Iwan Fals yang diberi judul Negara. Lirikan lagu ini sangat relevan untuk mengetahui dampak yang telah dilakukan oleh Pemerintahan Aceh umumnya dan Pemerintahan kabupaten/kota khususnya. Apakah cuplikan lagu tersebut sudah terpenuhi? Tentu, rakyatlah yang sangat mengetahuinya sebagai bagian utama penerima manfaat dari proses-proses pembangunan itu sendiri.

Upaya yang dilakukan oleh aparatur pemerintahan (baca : pelayan rakyat) untuk mewujudkan lirik lagu diatas setidaknya dapat dipenuhi melalui pembangunan. Pelaksanaan pembangunan membutuhkan serangkaian kegiatan seperti perencanaan, pelaksanaan, monitoring dan evaluasi yang dihasilkan secara bersama oleh parapihak, yakni eksekutif, legislatif dan komponen rakyat. Lazimnya, proses pembangunan termaktub dalam Rencana Pembangunan Jangka Menengah (RPJM) Kabupaten/kota maupun Provinsi. Turunan agenda pembangunan dalam bentuk rangkaian program tergambar dalam Anggaran Pendapatan dan Belanja (APBK) Kabupaten/kota serta Provinsi.

Mengingat rakyat menjadi penerima manfaat langsung pembangunan, maka sangat diperlukan ruang partisipasi publik yang luas, baik dalam perencanaan, pelaksanaan serta monitoring dan evaluasi. Apakah ruang konsultasi tersebut tersedia dan efektif di 
kabupaten/kota? Tulisan ini ditujukan untuk menggugah parapihak tentang pentingnya ketersediaan ruang konsultasi publik serta strategi pembangunan kabupaten/kota pada masa yang akan datang, dengan acuan utama gagasan Aceh Baru dan tulisan Menakar Partisipasi Publik dalam Rekonstruksi Aceh Paska Tsunami (M. Rizwan; 2005) serta ulasan Majalah Tempo akhir tahun 2008.

Menurut teori, proses pembangunan yang dilakukan dapat dikritisi melalui dua konsep utama, yakni teori modernisasi dan teori dependensi. Dua teori ini saling bertolak belakang dan merupakan sebuah pertarungan paradigma hingga saat ini. Teori modernisasi merujuk pada Amerika Serikat yang berhasil dalam pembangunan ekonomi. Namun, kegagalan pembangunan di Afrika, Amerika Latin dan Asia menjadi awal lahirnya teori dependensi. Secara garis besar teori modernisasi merupakan perpaduan antara sosiologi, psikologi dan ekonomi. Teori dasar yang menjadi landasan teori modernisasi adalah ide Durkheim dan Weber

Teori dependensi menjadi sebuah perlawanan terhadap teori modernisasi yang menyatakan untuk mencapai tahap kemajuan, sebuah negara (wilayah) berkembang harus meniru teknologi dan budaya negara (wilayah) maju. Salahseorang ahli teori dependensi, Andre Gunder Frank (1984) mencoba mengembangkan teori dependensi dan mengemukakan pendapat bahwa keterbelakangan pada negara dunia ketiga justru disebabkan oleh kontak dengan negara maju. Frank memberikan kritiknya terhadap pendekatanpendekatan yang menjadi rujukan teori modernisasi, antara lain pendekatan indeks tipe ideal, pendekatan difusionis dan pendekatan psikologis. Teori dependensi bertitik tolak dari pemikiran Marx tentang kapitalisme dan konflik kelas.

Mengacu Rizwan (2005), dinyatakan bahwa teori lainnya yang dapat dijadikan rujukan adalah teori redistribusi pertumbuhan. Pandangan teori ini disuarakan oleh Owens (1987) yang menyebutkan hal terpenting dalam pembangunan adalah pembangunan manusia, bukan pembangunan benda. Pembangunan sepatutnya diarahkan kepada peningkatan mutu kehidupan manusia.

Tantangan serius dalam pembangunan adalah bagaimana memperbaiki kualitas kehidupan manusia. Peningkatan pendapatan 
memang penting, tetapi pembangunan menuntut lebih dari itu. Pembangunan mencakup pendidikan yang lebih baik, standar kesehatan dan gizi yang tinggi, berkurangnya kemiskinan, lingkungan yang bersih, pemerataan kesempatan berusaha, kebebasan individu yang lebih besar, dan kehidupan cultural yang lebih kaya (World Bank, 1991 dalam Nanang,1999)

Berikutnya, dinyatakan bahwa teori pertumbuhan baru ini dikembangkan oleh Korten (1990) dengan memijakkan kakinya pada pertumbuhan berkelanjutan yang didasarkan pada prinsip keadilan dan pemerataan. Teori ini sudah cukup memihak rakyat, namun lebih dipertajam dengan teori people centered development (PCD) atau pembangunan yang berpusat pada rakyat. Teori ini memberi tekanan kepada keberlanjutan (sustainability) dan demokratisasi (Korten, 1990 dalam Nanang 1999). Dua isu ini merupakan isu penting dalam teori yang digagas oleh Organisasi non-Pemerintah (Ornop).

Agenda kerakyatan diletakkan determinan (penentu) dalam struktur teori ini, karena latar belakang historis penyusunannya lebih banyak diwarnai oleh kesaksian terhadap penderitaan manusia berupa kemiskinan yang parah, perang dan akibatnya, kerusakan lingkungan hidup, peningkatan pertumbuhan penduduk yang sangat pesat dan disintegrasi sosial. PCD melihat pembangunan sebagai gerakan rakyat bukan sekedar kegiatan pemerintah dengan pendanaan luar negeri. Sistesis transformative yang ingin dibangun oleh PCD adalah mempertemukan isu-isu lingkungan, hak asasi manusia, perlindungan konsumen, gerakan perempuan dan perdamaian dalam satu gerakan yang seimbang (Nanang, 1999).

Tampaknya, teori ini sangat produktif untuk ditiru dalam penyusunan format kabupaten/kota yang diharapkan. Sehingga bisa berpihak kepada rakyat yang memerlukan kebebasan dari tekanantekanan sosial dan politik yang selama ini berlangsung. Pembebasan diri rakyat dari alienasi kultural yang secara sengaja dilakukan perlu juga dipikirkan secara lebih serius dengan membangun kabupaten/kota berbasiskan pada nilai-nilai agama dan kebudayaannya. Cernea (1993) menunjukkan bahwa sebab-sebab kegagalan pembangunan yang diprogramkan dengan menggunakan uang sebagai pemacu pembangunan karena tidak memperhatikan 
faktor sosial dan kultural. Belum dapat dipastikan adanya energi sosial yang dikembangkan untuk mendukung program pembangunan berkelanjutan. Dalam banyak kasus, pemerintah sering mendesakkan satu strategi dan konsep pembangunan tanpa banyak memberi perhatian pada pembentukan organisasi dan institusi tingkat basis (grassroots).

\section{Konsep Perencanaan Partisipatif dan Partisipasi Publik}

Perencanaan pembangunan yang partisipatif sebenarnya bertujuan untuk memperoleh kesepakatan bersama (collective agreement) melalui aktivitas negosiasi dan konsultasi yang melibatkan seluruh pelaku pembangunan (stakeholders). Ruang yang tersedia untuk proses ini berupa Musyawarah Perencanaan Pembangunan (Musrenbang) atau bentuk lainnya, mulai di tingkat Gampong hingga kabupaten/kota. Proses ini nantinya akan berujung pada Anggaran Pendapatan dan Belanja Kabupaten/kota (APBK).

Musyawarah dan tingkat partisipasi aktif rakyat merupakan mekanisme pengambilan keputusan yang diharapkan akan mengurangi konflik antar pelaku pembangunan. Agar konflik bisa minimal, ragam aktor pembangunan termasuk rakyat serta gagasan yang berkembang harus diserap secara aspiratif supaya tidak terjadi ketimpangan dan penyumbatan akses terhadap sumber daya pembangunan yang tersedia. Dalam hal ini, sangat diharapkan agar rakyat mendapat porsi yang adil dalam penyusunan rancangan masa depannya.

Partisipasi publik sekurang-kurangnya terdiri dalam tiga tradisi partisipasi, yaitu partisipasi politik, partisipasi sosial dan partisipasi warga. Partisipasi politik terlihat pada representasi dalam demokasi perwakilan. Dalam kerangka demokrasi, partisipasi politik merupakan inti dari demokrasi. Sebab, partisipasi dikaitkan dengan dengan proses politik demokratis. Dalam proses politik yang demokratis, partisipasi politik melibatkan interaksi perseorangan atau institusi, seperti partai politik, dengan pemerintah. Partisipasi politik diungkapkan dalam tindakan seorang individu atau kelompok terorganisir untuk melakukan pemungutan suara, kampanye, protes, 
untuk mempengaruhi wakil-wakil pemerintah. Dengan demikian partisipasi politik lebih berorientasi pada 'mempengaruhi' dan 'mendudukan wakil-wakil rakyat' dalam lembaga pemerintahan ketimbang 'partisipasi aktif' dan 'langsung' dalam proses-proses kepemerintahan itu sendiri (Suhirman, 2003 dalam M. Rizwan Ali, 2005).

Berikutnya dijelaskan bahwa dalam partisipasi politik rakyat baik secara individu atau organisasi menyuarakan kepentingan dan keinginan mereka dalam ruang yang terletak antara rakyat dan negara. Ruang itu disebut sebagai civil society. Partisipasi politik dapat berbentuk tindakan-tindakan politik oleh aktor-aktor yang mendefinisikan dirinya berdasarkan kepentingan-kepentingan politik. Aktor-aktor itu adalah individu dan organisasi dalam rakyat.

Kedua, partisipasi sosial; partisipasi yang berorientasi pada perencanaan dan implementasi pembangunan. Menurut Steifel dan Wolf (1984) mengatakan bahwa partisipasi merupakan upaya terorganisir untuk meningkatkan pengawasan terhadap sumber daya dan lembaga pengatur dalam keadaan sosial tertentu oleh pelbagai kelompok gerakan yang sampai sekarang dikesampingkan dalam fungsi pengawasan. Dalam pengertian ini, partisipasi ditempatkan di luar negara atau lembaga-lembaga formal pemerintahan (Suhirman 2003).

Ketiga, partisipasi warga; jika partisipasi politik menekankan pada prinsip keterwakilan dan partisipasi sosial menempatkan partisipasi di luar lembaga pemerintahan, maka partisipasi warga bersifat langsung dalam pengambilan keputusan pada lembaga dan proses kepemerintahan. Konsep partisipasi warga telah mentransformasikan makna partisipasi menjadi "dari sekedar kepedulian pada 'penerima derma'atau 'kaum tersisih' menuju kepedulian dengan pelbagai bentuk keikutsertaan warga dalam pembuatan kebijakan dan pengambilan keputusan di berbagai gelanggang kunci yang mempengaruhi kehidupan mereka" (Gaventa dan Valderama dalam Suhirman, 2003). Konsep ini akan menutup kelemahan sistem perwakilan politik, meningkatkan makna partisipasi, meningkatkan kepercayaan publik terhadap lembaga pemerintah dan sekaligus 
mendorong percepatan lahirnya pemerintahan yang baik (good governance).

Dengan demikian partisipasi perencanaan pembangunan memiliki beberapa kriteria. Pertama, adanya upaya pelibatan seluruh pelaku pembangunan (stakeholders). Kedua, adanya upaya untuk membangun dan memperkuat kemampuan rakyat, baik secara individu atau organisasi. Ketiga, adanya proses konsultasi publik melalui urun rembuk yang mengarah kepada lahirnya kesepakatan kolektif. Keempat, adanya mekanisme yang menjamin rakyat bisa mengawasi jalannya pembangunan yang digerakkan pemerintah. Kelima, adanya usaha pemberdayaan rakyat melalui kegiatan pembelajaran kolektif yang merupakan bagian dari proses demokratisasi.

Penguatan partisipasi publik dalam proses pembangunan di kabupaten/kota sebaiknya dibangun atas landasan-landasan tersebut. Sebab, ketika program pembangunan hendak dilaksanakan maka dapat dipastikan adanya reaksi yang beragam. Tidak jarang reaksi tersebut adalah penolakan karena program pembangunan tidak sesuai dengan aspirasi dan kebutuhan rakyat. Misalnya saja penolakan rakyat terhadap rencana penambangan batu granit di kawasan Aceh Selatan beberapa waktu lalu. Banyak rakyat melakukan penolakan karena tidak jelasnya proses yang akan dilakukan, baik mengenai pembebasan tanah serta peluang kerja yang akan diperoleh oleh rakyat sekitar. Hal ini terjadi karena rencana penambangan tersebut tidak membuka ruang konsultasi yang luas dengan rakyat sekitar sehingga lahirnya kesepakatan kolektif bagaimana proses yang akan dilaksanakan.

Mobilisasi tidak sejalan dengan prinsip partisipasi yang sepatutnya menjadi wacana penting dan dilaksanakan dalam proses pembangunan di Aceh. Langkah pemerintah sebatas mengumumkan supaya rakyat berpartisipasi dalam menyusun format Aceh Baru, seperti yang telah dilakukan melalui media atau sarana lainnya belumlah cukup. Sebab, partisipasi yang terserap oleh pengumuman tersebut sangat terbatas hanya di kalangan intelektual dan sejumlah Organisasi Masyarakat Sipil (OMS), sementara partisipasi rakyat secara luas dikhawatirkna tetap belum terserap. 
Mobilisasi biasanya hanya dilakukan dengan dua jalan, pertama dengan cara-cara persuasif (misalnya pemberian ganjaran atau rewards, bujukan, persetujuan dan manipulasi), dan kedua dengan cara-cara koersif (misalnya penggunaan kekerasan atau ancaman kekerasan). Tentu saja kita tidak menginginkan hal ini terjadi ditengah-tengah musibah yang sedang menimpa rakyat Aceh. Pemerintah perlu memastikan bahwa praktik-praktik mobilisasi ini bisa dicegah dari tingkat provinsi hingga ke gampong-gampong di Aceh.

\section{Penutup: Membangun dengan Hati untuk Kesejahteraan Rakyat}

Pada edisi akhir tahun 2008, Majalah Tempo menampilkan tulisan tentang 10 Tokoh 2008 "Mereka Bekerja dengan Hati Menggerakkan Daerah". Para tokoh yang dimuat tersebut merupakan pilihan juri yang dibentuk oleh Tempo dengan 3 (tiga) kriteria yakni pelayanan publik, transparansi, dan keramahan pada dunia usaha. Tokoh-tokoh tersebut adalah (1) Jusuf Serang Kasim (Walikota Tarakan-Kalimantan Timur); (2) Untung Sarono Wiyono (Kabupaten Sragen-Jawa Tengah); (3) Joko Widodo (Walikota Solo); (4) Herry Zudianto (Walikota Yogyakarta-DIY); (5) Ilham Arif Sirajuddin (Walikota MakassarSulawesi Selatan); (6) Djarot Saiful Hidayat (Bupati Blitar-Jawa Timur); (7) David Babihoe (Bupati Gorontalo-Gorontalo); (8) Anak Agung Gde Agung (Bupati Badung-Bali); (9) Andi Hatta Marakarma (Bupati Luwu Timur-Sulawesi Selatan); dan (10) Suyanto (Bupati Jombang-Jawa Timur).

Pelajaran penting yang dapat dipetik dari pengalaman 10 tokoh tersebut adalah : pertama, adanya teladan dan kejujuran. Kedua, ternyata daerah mampu mengurus diri sendiri. Ketiga, harus ada penolakan terhadap fenomena klasik birokrasi yakni korupsi, inefisiensi, bekerja tanpa visi. Keempat, komunikasi yang intens merupakan kunci keberhasilan, dan yang kelima adalah sabar mendengar keluhan rakyat serta bekerja untuk mencapainya.

Mengacu berbagai pengalaman pimpinan daerah tersebut, kita dapat menetapkan pilihan-pilihan yang sesuai dengan kebutuhan, kondisi wilayah, serta kultur rakyat setempat. Semua berangkat dari penetapan skala prioritas yang harus ditanggulangi. Namun, sekurang-kurangnya pemerintahan kabupaten/kota harus mampu 
menyelesaikan permasalahan pelayanan dasar; pendidikan, kesehatan, dan administrasi kependudukan.

Pada sektor pendidikan, hal-hal yang sengkarut berkisar pada kurangnya tenaga pengajar (distribusi guru), sarana dan prasarana yang kurang memadai, serta mahalnya biaya pendidikan. Sedangkan penanganan yang penting pada sektor kesehatan berkenaan kualitas pelayanan, kecukupan sarana dan prasarana, serta mahalnya biaya pengobatan. Berkenaan dengan sektor administrasi kependudukan keluhan utama yang muncul adalah jauhnya jaraktempuh antara rakyat dengan tempat pelayanan.

Lirik lagu Iwan Fals, ulasan Tempo, konsep pembangunan yang partisipatif serta Skenario Aceh Baru dapat dikombinasikan untuk mewujudkan Aceh yang gemilang. Untuk itu, keterlibatan seluruh komponen dalam perencanaan, pelaksanaan, serta monitoring dan evaluasi dalam pembangunan menjadi sangat penting. Dalam hal ini, pemerintah sangat penting menjadi pendorong utama agar seluruh agenda perubahan dapat terlaksana. Hendaknya, pemimpin harus bekerja dengan hati dan memastikan kepentingan rakyat sebagai prioritas utama. Mengapa? Pemimpin adalah pelayan bagi yang dipimpin, bukan sebaliknya. 